is also interesting to note that Denmark has recently enacted somewhat similar legislation. ${ }^{30}$ It has established a system of independent courts to deal with labor disputes, but, curiously enough, left the selection of judges to private organizations. This is certainly a departure from the usual course of procedure, involving as it does the court of highest instance within a particular field.

It is evident that the courts have been unable to bring about industrial peace in this country. There is some possibility that labor and capital will settle their differences without requiring outside intervention. The prevalent view, however, appears to be that the remedy must come through the legislatures. Probably the natural course for them to take will be in the direction of compulsory arbitration. The Kansas experiment may be the entering wedge, or it may show the impracticability of such a course. ${ }^{31}$ There undoubtedly is a solution to this problem, and it is to be hoped that the legislatures will make a serious effort to discover it. Certainly it would be a sinister confession of weakness if a democracy were to admit that it could devise no means to control and.put an end to private warfare between two such large groups of its citizens.

\title{
JUDGMENT OR SATISFACTION AS PASSING TITLE
}

"The controversy whether the title to a converted chattel vests in a defendant by simple judgment, or only after the satisfaction of the judgment, is, therefore, but another battle of the knights over the gold and silver shield. Under some circumstances the title changes' by the judgment alone; in other cases satisfaction is necessary to produce that result." "1

Such was the conclusion of Ames on the mooted question whether, in an action for conversion, the mere entry of a judgment for the value of the converted chattel, or the payment of the judgment, passed the title of the chattel to the converter. The early cases stated that title passed by the judgment. ${ }^{2}$ It has long been the fashion, however, to say that, not the judgment, but only satisfaction of it passes the

${ }^{20}$ The Danish Labor Court: (Dec. 9, I920) Industrial Information Service 3-6.

2 This and other measures will be taken up in a further comment.

' Ames, The Nature of Ownership (1890) 3 HARv. L. REv. 23, 313, 327, 3 Select Essays in Anglo-American Legal History (19..) 561, 578, Lectures in Legal History (I9I3) 209.

'Adams v. Broughton (I708, K. B.) 2 Strange, I077; Smith v. Gibson (1737, K. B.) I Cas. T. Hardw. 3r9; Browin v. Wotton, (I606, K. B.) Cro. Jac. 73, Yelv. 67, Moore, 762; Bishop v. Montague, (I60r, C. P.) Cro. Eliz. 824. See also Buckland v. Johnson (1854, C. P.) I5 C. B. 145; Cooper v. Shepherd (1846, C. P.) 3 C. B. 265 ; note to Bennett v. Brandao (1843, C. P.) 6 Man. \& Grang. 630, 640; Kitchen'v. Campbell (I772, C. P.) 3 Wils. 304, 309, 2 Wm. Black. 779, 827; see also discussion of the earlier cases in Brinsmead $v$. Harrison (187r) L. R. 6 C. P. 584, (1872) L. R. 7 C. P. 547. For cases in the Year Books see note 5, infra, and cf. Keil. $58 \mathrm{~b}$. 
title. $^{3}$ Thus the court in Decker v. Milwaukee Cold Storage Co. (I920, Wis.) I80 N. W. 256 , states that, by the "great weight of authority", it is only the satisfaction of the judgment which, by law, divests the original owner of his title. Much of the difficulty and much, though not all, of the conflict in the cases comes from the use of the uncertain and indefinite term "title" to express varying legal situations for which a closer definition is desirable. "Title" is a concept of "much agility. Generally, when it appears, we find in it a tendency to flit here and there with a suddenness which is surprising, and hence we should not be surprised to find it possessing these characteristics in the situation under discussion." The confusion comes from the fact that title is applied to an aggregate-a "bundle" - of legal relations, and we find the term used indiscriminately to indicate a bundle of various sizes.

Thus, if the term means the passing of all legal interest in the chattel from the original owner, title does not pass until satisfaction of the judgment; if, however, it means the passing of some interest from the owner, it passes at least on judgment, if not before. ${ }^{5}$ Although Ames adhered to the traditional term "title", he had this distinction clearly in mind in the passage quoted above, where he suggests that some

${ }^{3}$ Brinsmead v. Harrison, supra note 2; Atwater v. Tupper (1877) 45 Conn. 144; Miller v. Hyde (1894) 16I Mass. 472, 37 N. E. 760; Tolman Co. v. Waite (1899) 199 Mich. 341, 78 N. W. 124; Risssell v. McCall (1894) 14r N. Y. 437, 36 N. E. 498 ; see also 2 Kent, Commentaries, * 388 . See cases collected in I5 Ann. Cas. 454, note, 26 R. C. L. II57, 38, Cyc. 2 II2. In 38 Cyc. 2112 , many cases are cited as holding in accord with the old rule. Most of them may be distinguished as pointed out in this comment. In accord with the former rule, however, see Hydé v. Kiehl (1898) $183 \mathrm{~Pa}$. 4I4, 38 Atl. 998; Merrick's Estate (I842, Pa.) 5 W. \& S. 9, I7; Wilburn v. Bogan (1842, S. C.) I Spear, I79; Murrell v. Johnson's Administrator (1807, Va.) I H. \& M. 449; and cf. Parmenter v. Barstow (I899) 2I R. I. 410, 43 Atl. I035.

- See Corbin, What is a Transfer of Title (1920) 29 Yale Law JouRnal, 429; also, as to the somewhat similar term "own," cf. Cook, Hohfeld's Contribution to the Law (I9I9) 28 id. 72I, 725.

The language of the cases in the Year Books on election of remedies"disseisin by election"-indicates that the election to divest the property out of oneself was made by the bringing of the action. (I440). Y. B. Ig Hen. VI, p. 65, p1. 5; (I462) Y. B. 2 Edw. IV, p. I6, pl. 8; (I405) Y. B. 6 Hen. VII, p. 8, pl. 4 . Compare as to realty, Co. Lit. $323 \mathrm{~b}$, and see Holmes, J., dissenting, in Miller $v$. Hyde, supra note 3; see also Bordwell, Property in the Trespasser (IgI6) 29 HARv. L. Rev. 374, 385. This was the view of Anderson and Warburton, JJ., in Bishop v. Montague, supra note 2 ; cf, cases in note 2, supra. Yet since a nonsuit was and is so freely permitted and is no bar in another suit the question should not be of importance. See Co. Lit. I39 a; Outhwaite v. Hudson (1852) 7 Exch. 380; Bacon Abr. tit., Non-Suit: I8 C. J. 1153, II7I. As Holmes says, in Miller $v$. Hyde, supra note 3, "An election is determined by judgment." There are, however, cases holding that the election is finally and conclusively made by the bringing of the suit. Ireland v. Waymire (I920, Kan.) IgI Pac. 304, criticised in (1920) 30 Yale LAW JouRnaL, 206, citing Keener, Quasi-Contracts (1893) 203-213; Corbin, Waiver of Tort (19I0) I9 YALE LAW JournaL, 22I, 239; (I9I9) 28 id. 409 . In Brown v. Wootton, supra note 2 , the court treated the judgment rather as res judicata than as an election. 
interest passes on judgment and the rest on satisfaction. In fact, he gives a new twist to the term, showing it to be a variable thing, while the usual fallacy is to use it in the belief that it means a fixed and certain thing. The real issue therefore is, to ascertain just how much of a legal interest passed from owner to converter at each stage of the proceedings.

Even by the conversion the converter has bettered his legal position somewhat with respect to the chattel, for, by the more general rule, he gets "title as against all the world except the true owner" and those claiming under the true owner, i.e., he may sue or defend on the strength of his possession. ${ }^{6}$ But since disseisin of chattels does not carry as important results from the standpoint of remedial relief as did the old disseisin of realty, ${ }^{7}$ the converter has acquired as against the true owner little more than a liability to a judgment of some kind. Suppose such judgment to be entered. If it is for the redelivery of the chattel, obviously "title" has not passed, that is, the converter has acquired no further legal interest in the chattel. If it is for the value of the chattel, has a further legal interest been acquired? In one respect at least, there has, since a former judgment may be pleaded under the doctrine that no one is to be sued twice for the same wrong. After a judgment for the value of the chattel, the original owner can no longer sue the converter for the chattel itself or-for its value. Trespass, trover, implied assumpsit, detinue, and, it seems, replevin, or their descendants under the codes, all are barred by the judgment in trover. ${ }^{8}$ The converter is immune from suit and thus has approached-complete ownership. What does he lack?

Before attempting an answer to this question, it may be well to state

'By the weight of authority title in a third party is not a defense to an action for conversion, unless the defendant connects himself with such title. See cases collected, 38 Cyc. 2062; 26 R. C. L. II4I. .

"See Bordwell, Seisin and Disseisin (I92I) 34 HARv. L. REv. 592, 604, 609 ; and see also articles by Bordwell, supra note 5, and Ames, supra note $\mathrm{I}$.

- Nemo bis vexari debet pro eadem causa. Kitchen v. Campbell, supra note 2; Sinith v: Gibson, supra note 2; Ferrer's Case (I598, C. P.) Coke, Pt. 6, 7a; Singer \& Co.v. Yaduski (1902) II Pa. Dist. Rep. 57I; Rembert v. Hally (I850, Tenn.) Io Humph. 513; Lacon v. Bamard (1627, C. P.) Cro. Car. 35; Wooley v. Carter (1823, N. J. L.) 2 Halst. 45 ; Lovejoy v. Wallace (I865, U. S.) 3 Wall. I, I9; Rauer v. Rynd (1915) 27 Calif. App. 556, I50 Pac. 780; Mead v. Mead (I9II) II5 Minn. 524, I32 N. W. II32; Smith v. Clark (I909) 37 Utah, II6, 106 Pac. 653, 26 L. R. A. (N. s.) 28I, note; Oliver v. Grand Ronde Grain C $\dot{o}$. (Igr4) 72 Ore. 46, I42 Pac. 54I. See cases collected 23 Cyc. I32r. The judgment must of course be for the value of the chattel and not merely damages for the taking, i. e., the issue must be the same. Lacon $v$. Barnard, supra. It might be thought that the unpaid plaintiff should still have replevin. While the authority is scanty, this does not seem to be true. Cf. Rauer v. Rynd, supra; Mead v. Mead, supra. And if it were, we should have this dilemma, that the plaintiff would be entitled to possession notwithstanding the judgment in trover, and if defendant refused to give up possession on demand he would be guilty of conversion and then trover would again lie! 
another point as to which the courts are coming more and more into general agreement: It is a general principle of the law of torts that a judgment against one of two joint tort-feasors is no bar to a suit against the other until the judgment is satisfied.9. Unlike the rule against double vexation, there is no socially desirable principle that a man should be relieved of his tort by the mere entry of a judgment, which has not been paid, against another. So, in accord with this principle, we find many cases allowing successive suits against joint converters or against successive converters brought before the first judgment for the value of the chattel.10. In fact almost all of the cases involve this point, and, while the rule of law will be stated broadly that satisfaction is necessary to the passing of title, actually it will be only a case of a joint wrong or of a conversion from the converter. ${ }^{11}$ Such was the actual decision in Decker v. Milwankee Cold Storage Co., $s u p r a$, where a factor had wrongfully transferred the plaintiff's goods to the cold storage company. It was held that an unsatisfied judgment for conversion against the factor did not bar replevin by the owners againist the storage company. Each case it cites to show the "great weight of authority" presents only an analogous situation and not a case where one is claiming by transfer from the judgment debtor after the judgment.

Hence we see that joint or successive converters may be sued until satisfaction is obtained, while the mere entry of judgment gives an immunity from suit to the defendant converter who is sued. What is the position of those who take from the converter after judgment? Ames suggested acutely, ${ }^{12}$ and his suggestion has been adopted by learned commentators, ${ }^{13}$ that the answer to this question should depend upon who has possession at the time of the judgment. If the converter has possession at the time of the judgment, "the converter's possession, "being thus set free from adverse claims, changes into ownership," and subsequent possessors are protected; whereas, if there is a change of possession before judgment against the converter, the new possessor

- That judgment against one of two joint tort-feasors without satisfaction is no bar to a suit against the other-the usual rule in America-see Livingston v. Bishop (I806, N. Y. Sup. Ct.) I Johns. 290; Litchfield v. Goodnow (1887) I23 U. S. 549, 8 Sup. Ct. 210; Lumber Co.v. Banks (I907) I18 Tenn. 627, 102 S. W. 79; but see contra, Petticolas v. Richmond ( 1897 ) 95 Va. 456,28 S. E. 566 ; and Brinsmead $v$. Harrison, supra note 2, (criticised by Ames, op. cit. note $\mathrm{I}$ ). For cases collected see 23 Cyc. 1212.

${ }^{10}$ Such were the cases in note 3 supra. Thus in Miller $v$. Hyde there were successive conversions, and in Atwater $v$. Tupper there was a joint conversion. See also Matthews v. Menedger ( 1840, C. C. $7^{\text {th }}$ ) 2 McLean, I45; Sharp v. Gray (1844, Ky.) 5 B. Mon. 4; Hopkins v. Hersey (I84r) 20 Me. 449 ; McGee v. Overley (185I), 12 Ark. I64; Dow v. King (1889) 52 Ark. 282, 12 S. W. 577; Singer Mfg. Co. v. Skillman (1890) 52 N. J. L. 263, I9 Atl. 260.

${ }^{11} \mathrm{Cf}$. cases in notes 3 and ro supra.

"Ames, op, cit., note $I$.

${ }^{23}$ See Notes (Ig02) I6 HARv. L. Rev. I3I. 
is not so protected. On the surface at least there seems to be no logical sequence from cause to result. Is it, as Ames suggests, analogous to the running of the statute of limitations where "possession ripens into "ownership?" There is a certain analogy, it is true, but it is believed that the reason for the rule suggested by Ames goes deeper. It is simply an application of the rule against double vexation to allow the taker from the judgment debtor to be in as good a position as the debtor is and to have a like immunity from suit. Hence under this view neither the converter nor those claiming under him after the judgment, i. e., in privity with him, may be sued.14 But suit may be brought against all others not occupying this favored position. ${ }^{15}$ Or, as is so often expressed, judgments bind parties thereto and their privies, and as those claiming under the converter after the judgment are in privity with him, the judgment is binding upon them and in their favor. ${ }^{16}$

Our sympathies for the unpaid plaintiff may lead us to object to this view, but it is thought that from the standpoint of reason and justice there is much to be said for it. If the converter finds that his judgment does not enable him to sell the chattel with any degree of safety, his immunity from another suit is of indifferent value. This may not cause us discomfort, since with an unsatisfied judgment against him he is not in a position to make any particular appeal to our sympathies. And the rule against double vexation is probably only partly for his protection, for the courts themselves need some protection and this is a device to prevent litigation from lasting forever. ${ }^{17}$ But the position of the taker from the converter is more appealing. Acting subsequent to a judgment for the value of the chattel, and quite probably upon

\footnotetext{
${ }^{14}$ For good discussion see Barb v. Fish (I847, Ind.) 8 Blackf. 481,485 ; see also (I844) 3 AMER. L. MAG. 49, infra note I8. A creditor of the converter may take the chattel on execution against the converter. Rogers $v$. Moore ( 1838 , S. C.) Rice, 60; Norrill v. Corley (1828, S. C.) 2 Rich. Eq. .288; Forman v. Nielson (1846, S. C.) 2 Rich Eq. 387; Norris v. Beckley (1818, S. C.) 2 Const. Rep. '228; but cf. Bush v. Bush (1847, S. C.) I Strob. Eq. 377. In Eckert v. Truman (IgI4). I63 App. Div. I7, I48 N. Y. Supp. 48, it was said that while satisfaction of a judgment for conversion was necessary for the passage of title, "still the act of suing for conversion did change plaintiff's position," and he was no longer entitled to possession of the chattel. Hence the converter and her son to whom she claimed to have sold the chattel were not guilty of contempt of court in refusing to deliver it over to the plaintiff. For a somewhat similar situation, cee Deitz v. Field (I896) ro App. Div. 425, 4I N. Y. Supp. 1087; but see Union Pac. Ry. v. Schiff .(I897, S. D. N. Y.) 78 Fed. 216, (1898, C. C. A. 2d) 86 Fed. r023.

${ }^{25}$ As above noted, the usual case is that of the joint wrong-doer. See notes 3 , IO, and II supra. As to those who take from or dispossess, the converter prior to judgment, see Morris v. Robinson (1824, K. B.) 3 Barn. \& Cres. 196.

${ }^{16}$ Lovejoy v. Murray (I865, U. S.) 3 Wall. I, 18; Litchfield v. Goodnow, supra note $9 ; 23$ Cyc. 1227, 1253, I259.

${ }^{17}$ See remarks in Ferrer's Case, Kitchen v. Campbell, and the other cases cited in note 8 supra, especially Lovejoy v. Murray, supra note 16 , at p. 19.
} 
faith of it, he surely is more deserving of protection than the man who has had his election of. remedies and has taken his choice, who has chosen to pursue that course which he thought would bring him the most advantage, and who, moreover, has had the opportunity of enforcing his judgment by levying execution on the chattel itself while it was in the converter's hands. There is some support for this view in the cases, but there are few direct precedents on the point and they are not harmonious. Some of the cases cited by Ames fail to support his position. The issue is obscured by the general statement that "title" passes at one time or another. ${ }^{18}$ But the cases which do not afford protection by the judgment to those claiming under the judgment debtor surely reach an anomalous result, for the converter-perhaps an intentional and malicious wrong-doer-is no longer subject to a suit, while his innocent victims are. Some way should be sought in the event of such a holding, to avoid the ruling that the initial converter cannot again be sued. Perhaps it might be said that the action resulting in the judgment put in issue the title but not the immediate right to possession, which could be sued upon in a subsequent action of replevin. Yet this seems unsound, for the action does put in issue also the question of possession. ${ }^{19}$ Ames' view that one claiming under the judgment debtor by a transfer after judgment is protected would appear to be the sounder. Moreover, it avoids another anomaly, that of shielding the hardened converter who knows the law, for he will either not attempt to sell the chattel concerned in the judgment or will pick his victim with care before he vanishes. Any unexpected rule of law-any rule opposed to ordinary business practice-puts him who has had experience with it and knowledge of it at an advantage over

\footnotetext{
${ }^{18}$ Only in Barb v. Fish, supra note 14, does there seem to be an appreciation of the point that title included many legal relations, not all of which change at any one time. Ames' position is in general supported by the cases cited in note $\mathrm{I}_{4}$, though some of them speak of the judgment as passing title, i. e., the old common-law rule. As contra, should probably be stated cases where it is said that satisfaction is necessary, and no point is made whether the defendant claims under and subsequent to the former judgment or not. Ledbetter $v$. Embree (I895) I2 Ind. App. 617, 40 N. E. 920; Spivey v. Morris (I856) I8 Ala. 254; Osterhout v. Roberts (1827, N. Y. Sup. Ct.) 8 Cow. 43; Goff v. Craven (I884, N. Y. Sup. Ct.) 34 Hun, I50 (see criticism by Ames, op. cit. note I). In Spivey v. Morris and Osterhout $v$. Roberts, however, the defendant did not show himself in privity with the judgment debtor after the judgment and hence the cases are merely similar to those in notes 3 and Io supra. In an interesting article, Transfer of Personal Property by Judgment (1844) 3 Amer. L. MAG. 49 the conclusion is reached "that a judgment in trespass or trover without satisfaction will not transfer the title to the defendant, though such judgment is pleadable in bar to any action by the same plaintiff and his privies, against the same defendant and his privies."

${ }^{10}$ See note 8, supra. The crux of the matter is here, for surely we should not wish to treat the converter more gently than his transferee. Those who would favor the unpaid plaintiff should attack, therefore, the whole rule of the binding force of former judgments.
} 
the ordinary innocent law-abiding citizen, and this is thought to be such a rule. ${ }^{20}$

Should the converter secure from the judgment also an immunity from self-help, i. e., from a retaking of the chattel by the owner? An English case held that the owner might himself retake his chattel from the converter in spite of a judgment for its value in his favor. ${ }^{21}$ This does not conflict with our rules of policy suggested above, but it may be questioned how far, in view of the desirability of avoiding free fights, self-help should be available when court aid is not. It has been held in New Hampshire that a retaking by the owner after jurdgment but before satisfaction makes the owner liable in trover to the converter after the latter has paid the judgment. ${ }^{22}$ This result seems preferable, though it is placed on the fiction-unnecessary under Ames' reasoning-of "title relating back" to the conversion or the judgment when satisfaction is at length made. ${ }^{23}$

Decker v. Milwaukee Cold Storage Co., therefore, states only the ordinary rule applicable to joint or successive converters. To explain the decision in terms of the passage of title does not solve more difficult questions with which the court may be confronted in the future. It may then be desirable to point out that, while joint or successive wrongdoers are not protected by a bare judgment against one of their number, yet such a judgment will be protection both to those. who are parties to it and to those who claim under parties to it.

$$
\text { C: E. C. }
$$

\section{CRIMINAL RESPONSIBILITY OF PARENT WHO REFUSES TO OBTAIN MEDICAL} TREATMENT FOR SICK CHILD

The increasing number of persons whose religious belief discountenances the use of medicine in the treatment of disease gives considerable importance to the interesting legal questions which arise when a parent, because of religious conviction, fails to provide medical attention for his sick child. Two fairly recent cases have expressed opposite views

\footnotetext{
${ }^{20}$ It might be claimed that only those who purchase from the judgment debtor - should be entitled to the protection of his judgment. It is thought, however, that the reasons suggested in the text are strong enough to justify protection for any kind of a taker from the converter after a judgment against the latter. Only then can the converter's immunity from further suit-except on the judgment debt-be made practically complete and effective.

${ }^{21}$ Ex parte Drake (1877) L. R. 5 .Ch. Div. 866.

${ }^{22}$ Smith v. Smith (1872) $5 \mathrm{I}$ N. H. $57 \mathrm{I}$; cf. Greer v. Lafayette County Bank (I898, Tex. Civ. App.) 47 S. W. 737; Acheson v. Miller (I853) 2 Oh. St. 203.

${ }^{2}$ The same rule applies to increase of the chattel prior to satisfaction. Hepburn v. Sewell (182I, Md.) 5 H. \& J. 2II; White v. Martin (1834, Ala.) I Port. 215. The doctrine of relation is criticised by Holmes in Miller $v$. Hyde, supra note 3, and by Ames, op. cit. note I. In Bacon v. Kummel (I866) I4 Mich. 201, it was held not to apply so as to make an otherwise rightful act a trespass. Cf. Third Nat'l Bank v. Rice (1908, C. C. A. 8th) I6I Fed. 822, I5 Ann. Cas. 450, note.
} 